\title{
Method validation for protein quantitation of fish muscle tissues from Lake Taal, Batangas
}

\author{
David John Eliezar Delima, Phoebe Trio* \\ Chemistry Department, College of Science, De La Salle University - Manila, 2401
}

\begin{abstract}
Lake Taal is one of the largest producers of inland fish in the Philippines and has one of the largest freshwater wet markets in Luzon. These unregulated wet markets sell fishes in unreasonable prices and thereby, exploit the knowledge of consumers on the validity of the prices. This study was designed to quantify the proteins in fish muscle tissues and to validate the effectivity of the various protein quantitation methods. Twelve different species of fish samples were freshly collected from Lake Taal. Muscle tissues were removed and lyophilized before subjecting to comparative protein quantitation methods using direct photometry, ovalbumin assay, and Bradford's assay. These techniques were selected due to their accessibility and the use of photometry for quantitation. The results show that the means were significantly different for all the methods according to ANOVA. These results were confirmed with post-hoc Tukey HSD test, Scheffe test, and Bonferroni and Holm multiple comparison (BHMC) tests with $p<0.01$. Bradford's Assay was the ideal method with an RSD of less than $1 \%$ for all the samples, with no negative concentrations, and with concentration ranging from fifteen to twenty percent. $P$. leopardus had the highest amount of proteins, followed by $M$. cephalus, L. plumbeus, $C$. chanos, $H$. quoyi, and $A$. semipunctata. Interestingly, the study revealed that $O$. niloticus, which is one of the species with a high market price had the lowest protein concentration. With these results, the lowly commercialized fishes such as M. cephalus, L. plumbeus, $H$. quoyi, and $A$. semipunctata which are used as gamefish, fish bait, and aquarium displays should be commercialized more than the unstable populations of $P$. leopardus and $C$. chanos. Overall, this study revealed comparative information on protein quantitation methods, and market pricenutritional values correspondence.
\end{abstract}

Keywords: protein quantitation, method validation, fish, Lake Taal

*Author to whom correspondence should be addressed; email: phoebe.trio@dlsu.edu.ph 


\section{INTRODUCTION}

The fish industry has been one of the main contributors on food consumption in the region for over decades, and the Philippines has been ranked $11^{\text {th }}$ in the world in 2017 for freshwater fish consumption (Helgi Library, 2018). The agricultural region is driven by fish produce coming from 460 million hectares of marine resources and 1.5 million hectares of freshwater or inland sources (Philippine Statistics Authority, 2017). Although the resource area of freshwater fishes is smaller than that of the marine fishes, local fishermen have been utilizing these aquatic boundaries for livelihood in rural areas - some of which are delivered to the urban regions. From 2016, a rise in commercial fishing, municipal fishing, and aquacultures have been observed and has shown that these modes are utilized by the urban region (Philippine Statistics Authority, 2017). Of the different fishing sectors, municipal fisheries and aquacultures are among those that are not regulated, and these emerging markets do not pass quality control - these markets are not even assessed. These markets exploit price values of these fishes. Aside from that, the threat to the stability of fish population and proper environment management is also emerging and may cause permanent damage to species distribution. Food security is vital to both the consumers and the aquatic species population and distribution.

Fish products from inland fishing contributes to over 30 million pesos to the economic revenues of the country (Philippine Statistics Authority, 2017). This is mainly contributed by the regions of Calabarzon, Mimaropa, Western Visayas, Zamboanga Peninsula, Soccsksargen, and the Autonomous Region of Muslim Mindanao. Each region contributes to over 300 thousand metric tons of fishes amounting to about 130 million pesos worth of annual revenues. Moreover, Luzon has 3 commercial fisheries capitals, 2 marine municipal fisheries capitals, 6 inland municipal fisheries capitals, and 3 aquaculture capitals. It can be said that Luzon has more of the inland resources compared to Visayas and Mindanao areas which have more of the marine resource capital. Consequently, Batangas, Luzon's strongest freshwater produce provider, holds one of the largest closed water fish markets - the Lake Taal. Aside from Laguna de Bay, Lake Taal is one of the major contributors of freshwater resource in the Philippines. However, this market does not undergo any quality assessment. Similarly, freshwater fishes do not have extensive biomolecular profiles which leaves consumers disinformed and uninformed about which species have high protein contents, and their respective costs may not reflect their nutritional content. The unregulated fish markets around Lake Taal pose a threat to food security as the lack of quality assessment and conservation management policies threaten species distribution and consumer relations. For these unregulated markets, consumers don't have the capacity to recognize or distinguish if the fishes they consume reflect the amount of money from which they are sold (in terms of their protein content).

The protein quantitation of the fishes found in Lake Taal gives an imperative assessment of the nutritional profiles as reference for conservation management on species distribution and cost correspondence in unregulated markets. There are no studies on the protein quantitation of the fish muscle tissues in Lake Taal that can be the basis of management of the unregulated inland fish markets. This study is the first to examine this as studies on nutritional values of fishes in the Philippines are limited, especially in Lake Taal. Largely enough, the protein content is sought more by consumers and defines a large part of its nutritional value as most of the parts of fishes consumed are proteinaceous tissues. The provision of information on the protein concentrations is important in supplementing their prices. Thus, this study was conducted to validate methods and perform comparative analyses on the total protein content of fish samples in 
Lake Taal via Bradford's assay, ovalbumin assay, and direct photometry.

\section{EXPERIMENTAL}

Sample Collection, Identification, and Processing. Twelve fresh fish samples were collected from Lake Taal in Batangas, in the second week of September, and were temporarily stored at $4{ }^{\circ} \mathrm{C}$ during transport. These fishes were the abundant in the area during the month of September. Upon arrival at the laboratory, the samples were transferred to a freezer at $-18{ }^{\circ} \mathrm{C}$ prior to lyophilization. Prior to processing, their binomial nomenclatures and morphological dichotomy were also identified through different published atlases as indicated in Table 1.

Similarly, the morphological descriptions of the fish samples were noted. The pelvic, pectoral, anal, caudal, and dorsal fins were noted to be either spiny or soft-rayed. The color of the body and the basal vents of the fish were also described, as well as the presence and color of a median lateral line. The sizes were classified as small, medium, or large, as well as the relative sizes of the scales. The presence of the scales, whether hardly bound or not, was also recorded.

Muscle Tissue Collection and Freeze-Drying. The muscle tissues were separated from the whole fish and were pre-frozen using a sealable bags. Pre-frozen process was done to avoid the formation of small ice crystals once rapid freezing is applied. To lessen restrictive channels in the matrix of the samples, they were subjected to slower freezing to form larger ice crystals with a pre-requisite of prefreezing (Labconco, 2010). The collected muscle tissues were freeze-dried to remove water content. After freeze drying, the samples were homogenized.

Extraction of Protein. Proteins from the 12 fish samples were extracted using a Tris- $\mathrm{HCl}$, buffer. Five milliliters of the buffer were used to extract the proteins from the lyophilized fish samples. The extraction protocol was similar to that used in protein extraction from animal tissues in Bio-Rad SDS-Polyacrylamide Gel Electrophoresis (PAGE) Protocols (BioRad Laboratories, n.d.), GE Healthcare Life Sciences Protein Extraction Protocol Handbook (GE Healthcare Life Sciences, 2014), and wood mortar protein extraction protocol (Rao, Li, Yang, Mad, \& Wangab, 2014). The extraction of proteins was necessary to reduce and to lyse the cell structures since the lyophilization process allowed for tight packing and crystallization of the cells allowing for lower efficiency of protein escape from the cell membrane; thus, may interfere with absorption values. Approximately 0.1000 grams of lyophilized samples in triplicated were solubilized with $5.00 \mathrm{~mL}$ of the extracting solvent. The mixture was then sonicated for 15 minutes at room temperature to avoid coagulation. The sonication process was followed by mixing

Table 1. The fish samples and their scientific names.

\begin{tabular}{cc} 
Fish Sample & Binomial Nomenclature \\
\hline Bangus & Chanos chanos (Bagarinao, 1994) \\
Dugong & Asterropteryx semipunctata (Myers, 1991) \\
Otip & Plectropomus leopardus (Choat \& Samoilys, 2018) \\
Tilapia & Oreochromis niloticus (Trewavas, 1983) \\
Biang Bato & Gobius paganellus (Carpenter, Smith-Vaniz, de Bruyne, \& de Morais, 2015) \\
Arruyo & Sarotherodon melanotheron (Trewavas \& Teugels, Sarotherodon, 1991) \\
Ayungin & Leiopotherapon plumbeus (Herre, 1953) \\
Banak & Mugil cephalus (Harrison, 1995) \\
Dangat & Ostorhinchus cavitensis (Allen, 1995) \\
Tawilis & Sardinella tawilis (Whitehead, 1985) \\
Siliw & Hyporhamphus quoyi (Collette, 1859) \\
Guno & Atherinomorus duodecimalis (Ivantsoff, 1984) \\
\hline
\end{tabular}


using a vortex for a minute. The sonicationvortex coupling was repeated for three times, and the mixtures were incubated at $56{ }^{\circ} \mathrm{C}$ for an hour. After an hour, the mixtures were sonicated for 15 minutes at room temperature, and centrifuged for 3 minutes. The extracted samples were vortexed to enhance solubilization of the proteins before spectrophotometry. For samples that were not analyzed immediately, they were stored at $4{ }^{\circ} \mathrm{C}$.

Photometry Analysis. One microliter of the extracted samples were mixed with $2.00 \mathrm{~mL}$ ultrapure distilled water and were vortexed for a minute. The absorbances of the extracted sample were measured using Hitachi U-2900 Spectrophotometer set at 260 $\mathrm{nm}$ and $280 \mathrm{~nm}$, and data were extracted using the UV Solutions 2.2. Software Program No.: $1212301-12$ in a medium response. The protein concentration was calculated using the equation $X(\mathrm{mg} / \mathrm{mL})=1.55 \mathrm{~A} 280-0.76$ A260, where $X$ was the protein concentration in $\mathrm{mg} / \mathrm{mL}$, and A260 and A280 were the absorbance values of the diluted extracted samples at $260 \mathrm{~nm}$ and $280 \mathrm{~nm}$ for ribonucleic acids and proteins, respectively (Ubiali, Cadei, \& Grigolato, 2004). For all the spectrophotometric measurements, an initiation delay of zero second, a baud rate of 4800, an 8N2 data format, and a CR
$280 \mathrm{~nm}$, respectively. Consequently, the amino acid residues tryptophan, tyrosine, and cysteine are strongly absorbing at $280 \mathrm{~nm}$. The equation given above shows the correction factor for protein quantitation when the sample is contaminated with DNA.

Ovalbumin Assay. To standardize the concentrations of the extracted sample and to reduce the errors coming from the absorption of the ribonucleic acids, ovalbumin standards were prepared. An approximately 5.000 $\mathrm{mg} / \mathrm{mL}$ Sigma Aldrich reagent grade ovalbumin standard was prepared and served as the stock solution. Then, the working standards were prepared ranging from $0-1$ $\mathrm{mg} / \mathrm{mL}$ concentrations. Three internal replicates and three external replicates were employed in this assay's standards. The volumes from the stock solution and the diluent are reported in Table 2.

The samples were prepared by taking 1.00 $\mathrm{mL}$ from the extracted samples, and addition of $4 \mathrm{~mL}$ ultrapure commercial distilled water. The standards and the diluted extracted samples were placed in quartz cuvettes and their respective absorbance values were detemined through U-2900 Spectrophotometer coupled with the UV Solutions software. The absorbances of the standards and the diluted extracted samples

Table 2. The cocktails of the standards used for the ovalbumin assay at $280 \mathrm{~nm}$.

$$
\text { Standard Label Protein Standard, } \mu \mathrm{L} \quad \text { Distilled Water, } \mu \mathrm{L} \quad \text { Concentration, } \mathrm{mg} / \mathrm{mL}
$$

\begin{tabular}{cccc}
\hline Blank & 0 & 3000 & 0.00000 \\
1 & 15 & 2985 & 0.02445 \\
2 & 30 & 2970 & 0.04890 \\
3 & 60 & 2940 & 0.09780 \\
4 & 240 & 2760 & 0.39120 \\
5 & 300 & 2700 & 0.48900 \\
6 & 600 & 2400 & 0.97800 \\
\hline
\end{tabular}

terminator were used in assessing the absorptions. The heterocyclic rings of DNA absorb strongly and weakly at $260 \mathrm{~nm}$ and were read at $280 \mathrm{~nm}$. The protocol was adapted and modified from the protein quantitation protocol using UV-Vis 
Spectrophotometry (Jasco Corporation, n.d.). Protein quantitation of the samples were done in triplicates (internal and external). This assay works by quantifying proteins through the absorption of tryptophan, tyrosine, and cysteine in protein samples.

Bradford's Assay. The stock protein standard (Sigma Aldrich reagent grade Ovalbumin) of $4.890 \mathrm{mg} / \mathrm{mL}$ was used to prepare the standards as shown in Table 3. Briefly, the standards were prepared by diluting the protein standard volumes with the corresponding ultrapure commercial distilled water to reach $1 \mathrm{~mL}$. Then, the solution was dissolved in $5 \mathrm{~mL}$ Sigma Aldrich Bradford's reagent (Coomassie Brilliant Blue - G250). Three internal replicates and three external replicates were employed in this assay's standards.

Similarly, the samples were prepared by pipetting $100.00 \mathrm{uL}$ of the extracted samples into clean and dried test tubes containing 5 mL Bradford's reagent. The standards and the diluted extracted samples were placed in plastic cuvettes and their respective absorbances were measured through U-2900 Spectrophotometer coupled with the UV Solutions software. The absorbances of the standards and the diluted extracted samples were read at $595 \mathrm{~nm}$. This analysis was done in triplicates (internal and external). The protocol was adapted and modified from the Bradford method for protein quantitation (Kruger, The Bradford method of protein quantitation, 2nd Edition, 2002). The cationic form of Coomassie Brilliant Blue G-250 will bind to proteins at the carboxyl groups (through covalent interactions) and through the amino acids (through ionic interactions) under acidic conditions. The complex formed ionizes the protein and reveals the hydrophobic amino acids that were hidden when the protein is in its native state. These hydrophobic regions non-covalently bind to the hydrophobic regions of the dye. These three interactions stabilize each other creating a substantial quantification technique for proteins.

Data Analysis. Kurtosis and Skewness values were calculated to determine if the distributions were Gaussian. Moreover, the analysis of variance (ANOVA) was performed and $P$-value of $<0.01$ to determine the statistical difference across the data array of the treated samples. The results of the ANOVA were confirmed via the post-hoc Tukey Honestly Significant Difference (HSD) test on multiple pairwise $Q$ critical comparison, Scheffe test on complex pairwise $T$ values comparison, BHMC tests on $P$-value evaluation and on Bradford's assay as control at $P$-value of $<0.01$.

\section{RESULTS AND DISCUSSION}

Lake Taal has been one of the largest providers of inland fish produce and the increasing exploitation of market prices, aquacultures, and fisheries post threat to food security. The profiling of protein concentration values of fish species in Lake

Table 3. The cocktails of the standards used in the Bradford's assay at $595 \mathrm{~nm}$.

Standard Label Protein Standard, $\mu \mathrm{L} \quad$ Distilled Water, $\mu \mathrm{L} \quad$ Concentration, $\mathrm{mg} / \mathrm{mL}$

\begin{tabular}{cccc}
\hline Blank & 0 & 1000 & 0.00000 \\
1 & 20 & 980 & 0.09780 \\
2 & 40 & 960 & 0.19560 \\
3 & 80 & 920 & 0.39120 \\
4 & 120 & 880 & 0.58680 \\
5 & 160 & 840 & 0.78240 \\
6 & 200 & 800 & 0.97800 \\
\hline
\end{tabular}


Taal is lacking. Thus, this is the first study to perform protein quantitation of fish muscle tissues in Lake Taal with validation of the techniques employed. This is to serve as reference for future conservation management and market monitoring.

\section{Protein Concentration in Fish Samples by Photometry. The non-destructive} photometry at $260 \mathrm{~nm}$ and $280 \mathrm{~nm}$ showed protein concentrations ranging from -3 to $11 \%$, which is not in agreement with reported values (Torry Research Station, n.d.). $O$. niloticus had the highest protein content at $10.9016 \%$, followed by L. plumbeus at $10.4000 \%, \quad C$. chanos at $9.3492 \%, S$. melanotheron at $8.9031 \%$, G. paganellus at $7.6402 \%$, and P. leopardus at 5.8333 (Table 4). The protein contents of $O$. niloticus, $C$. chanos, and P. leopardus were in agreement with their relative market prices and commercialization strengths (Trewavas, Tilapiine fishes of the genera Sarotherodon, Oreochromis and Danakilia, 1983; Bagarinao, 1994; Heemstra \& Randall, 1993). Although these species were classified by the International Union for Conservation of Nature as not vulnerable for extinction, $P$. leopardus's population is decreasing (Choat \& Samoilys, 2018) while O. niloticus's and $C$. chanos's populations are being threatened by exploitations of aquatic resources, modifications of natural systems, and invasions of alien species (Snoeks, Freyhof,
Geelhand, \& Hughes, 2018; Freyhof, et al., 2017). Moreover, O. niloticus has reports of potentiality as a pest. In contrary, L. plumbeus, S. melanotheron, and G. paganellus have lower commercialization strengths and typically used as displays in aquariums, gamefish, and fish baits (Herre, 1953; Trewavas \& Teugels, Sarotherodon, 1991; Maufe, 1986). The populations of these species are stable (Santos, B., et al., 2010; Carpenter et al., 2015), except for L. plumbeus which has a constant decline in population (Froese, Rainer, \& Daniel, 2010). Additionally, S. melanotheron is considered as pest (Trewavas \& Teugels, Sarotherodon, 1991). Species with stable populations and high protein contents but with lower commercialization, such as $S$. melanotheron and G. plumbeus, should be commercialized more than the unstable expensive species such as $P$. leopardus, $O$. niloticus, and $C$. chanos. S. melanotheron should be bred in close captivities, as well as $O$. niloticus, due to their pest nature. However, this is expensive to maintain. Aquacultures and fisheries should shift to commercializing $S$. melanotheron and G. paganellus as they have stable populations, high protein contents, and lower commercialization strengths, instead of only using these species as aquarium displays, gamefish, and fish baits. Similarly, negative concentrations were observed for $M$. cephalus, 0 . cavitensis, and $S$. tawilis, which is impossible as the samples are concentrated

Table 4. Protein concentrations (\% P) using the three methods employed.

\begin{tabular}{|c|c|c|c|c|c|c|}
\hline \multirow{2}{*}{ Species } & \multicolumn{2}{|c|}{ Photometry } & \multicolumn{2}{|c|}{ Ovalbumin } & \multicolumn{2}{|c|}{ Bradford } \\
\hline & $\% \mathrm{P}$ & $\%$ RSD & $\% \mathrm{P}$ & $\%$ RSD & $\% \mathrm{P}$ & $\%$ RSD \\
\hline C. chanos & 9.349 & 2.048 & 16.29 & 2.290 & 17.32 & 0.2228 \\
\hline A. semipunctata & 5.363 & 6.2669 & 11.03 & 3.607 & 16.65 & 0.1211 \\
\hline P. leopardus & 5.833 & 7.169 & 11.40 & 4.207 & 20.23 & 0.2396 \\
\hline O. niloticus & 10.90 & 6.899 & 18.74 & 1.547 & 14.44 & 0.1629 \\
\hline G. paganellus & 7.640 & 4.643 & 14.48 & 3.543 & 16.31 & 0.3064 \\
\hline S. melanotheron & 8.930 & 0.8161 & 15.78 & 0.3088 & 15.70 & 0.5424 \\
\hline L. plumbeus & 10.40 & 0.6922 & 16.55 & 0.1324 & 17.50 & 0.6558 \\
\hline M. cephalus & -3.818 & -30.81 & 5.815 & 1.353 & 17.70 & 0.1209 \\
\hline O. cavitensis & -0.7855 & -26.54 & 8.581 & 0.0815 & 15.89 & 0.2281 \\
\hline S. tawilis & -0.2538 & -51.35 & 10.10 & 0.2001 & 15.23 & 0.5264 \\
\hline H. quoyi & 3.118 & 1.969 & 5.634 & 0.1178 & 17.02 & 0.4046 \\
\hline A. duodecimalis & 4.057 & 1.046 & 6.252 & VolQm@8D, I & er 2,79 & 90. KIMTKA \\
\hline
\end{tabular}


(lyophilized) muscle tissues (Fig. 1). These negative values come from the negative function of the ribonucleic absorption. The ribonucleic absorption interferes largely to the absorptions of the aromatic amino acids $\mathrm{W}$ and $\mathrm{Y}$ in the sample; hence, lowering the protein concentrations as compared to the concentrations reported using other methods. Moreover, the protein concentration values for A. semipunctata, $H$. quoyi, and $A$. duodecimalis support these species' low commercialization strengths as they are used more as fish baits, game fish, and aquarium displays (Myers, 1991; Collette \& Su, 1986; Ivantsoff, 1984).

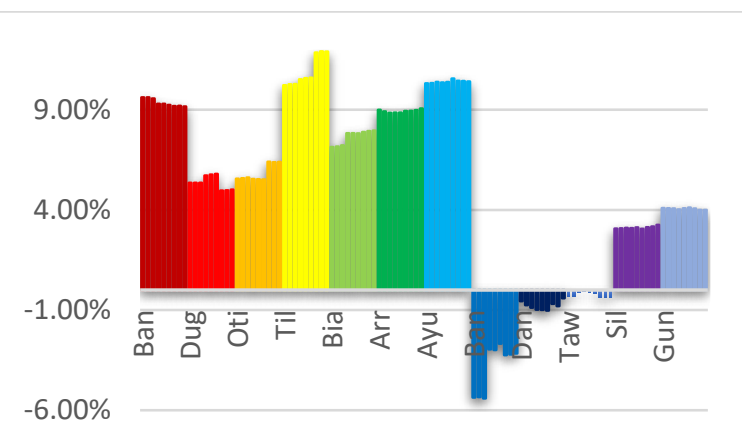

Figure 1. The protein concentration plot from the photometry at 260 and $280 \mathrm{~nm}$.

Comparatively, photometry analysis had the highest values for \% RSD with negative \% RSD from -26 to $-51 \%$, which are above the accepted values for replication. The distribution is Gaussian (Table 5). ANOVA revealed an $\mathrm{F}$ statistic value $(254.0951)>Q$ critical value (4.1498) which strongly suggested that the methods were significantly different at a $P$-value of $1.1102 \times 10^{-16}<$ 0.01. Post-hoc Tukey HSD test supported these findings by comparing $Q$ statistic values with a $P$-value of $0.0010053<0.01$ for all the comparisons, and a $Q$ critical of 4.1498: photometry vs 2 (a $Q$ statistic of 18.2578), photometry vs 3 ( $Q$ statistic of 31.7624). Evaluating $T$ statistic values, Scheffe test revealed the methods were significantly different at a $P$-value of $1.1102 \times 10^{-16}<0.01$ and $Q$ critical of 4.1498: photometry vs ovalbumin (a T-statistic of 12.9102), photometry vs Bradford (a T-statistic of $22.4594)$. The $P$-values were evaluated by the BHMC tests, which supported the arguments above with Bonferroni and Holm $P$ interference values of $0.0000<0.01$. The $\mathrm{BH}$ $T$-statistic values for the comparisons of photometry to ovalbumin was 12.9102 , and to Bradford was 22.4594. The statistical premises above suggested the limitations of Photometry from Ovalbumin and Bradford.

Protein Concentration in Fish Samples by Ovalbumin Assay. To remove the negative function and the interference of the ribonucleic absorption at $260 \mathrm{~nm}$, the photometry at $280 \mathrm{~nm}$ was used using ovalbumin assay.

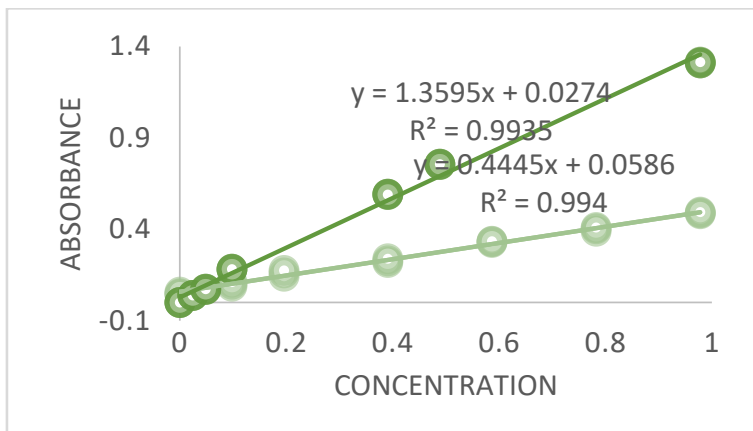

Figure 2. The plot of Absorbance vs. Concentration of Bradford's assay at $595 \mathrm{~nm}$ (lighter shade) and ovalbumin assay at 280 nm (darker shade).

The ovalbumin standards and their respective absorbances reflected a correlation coefficient of 0.9935 which indicated that the

Table 5. Skewness and Kurtosis values of the data arrays.

\begin{tabular}{ccc}
\hline Methods & Skewness value & Kurtosis value \\
\hline Photometry & -0.5075 & -0.7961 \\
Ovalbumin & -0.0144 & -1.3195 \\
Bradford & 0.8356 & 0.7962 \\
\hline
\end{tabular}


function $y=1.3595 x+0.0274$ can be used to quantify the protein concentrations of the samples (Fig. 2). The \% RSDs for all the standards were below $10 \%$ which showed the high precision in the preparation of the standards. This method reported concentrations ranging from $5 \%$ to $18 \%$ which is not in agreement with the accepted protein range (Torry Research Station, n.d.). The interferences coming from the ribonucleic acids are reduced in this method, making it more superior than photometry. However, ribonucleic acids absorb in this region but with lower intensity (Fig. 3), which makes it limited to the capacity of Bradford's assay.

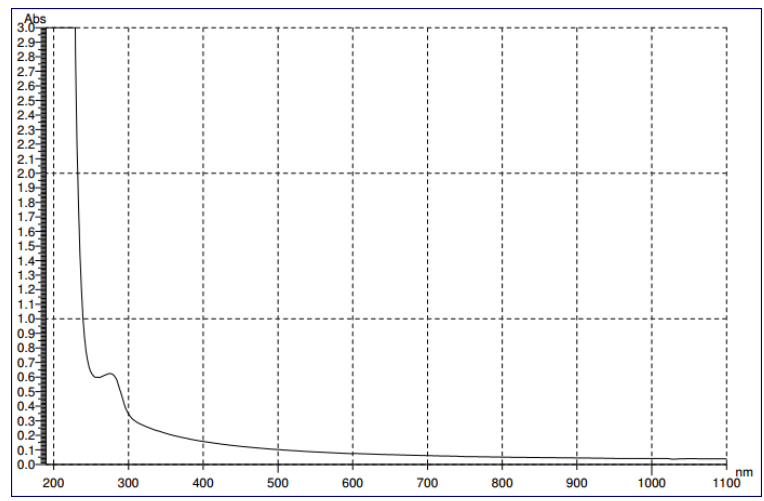

Figure 3. The absorption spectra of proteins from 190 to $1100 \mathrm{~nm}$ with an isolated maximum absorption at $280 \mathrm{~nm}$.

In this method, $O$. niloticus exhibited the highest protein concentration at $18.7433 \%$. It was followed by L. plumbeus at $16.5545 \%, C$. chanos at $16.2916 \%, S$. melantotheron at $15.7849 \%$, G. paganellus at $14.4832 \%$, and $P$. leopardus at $11.4035 \%$ (Table 4). Interestingly, these findings were not consistent with the values described by photometry (Fig. 4), but the species in the upper $50 \%$ were all the same. The findings of this method supported the recommendations in photometry that species such as $S$. melanotheron and $G$. plumbeus with stable populations and high protein contents but with lower commercialization should be commercialized more than the unstable expensive species such as $P$. leopardus, $O$. niloticus, and $C$. chanos. $S$. melanotheron should be bred in close captivities, as well as $O$. niloticus, due to their pest nature. Aquacultures and fisheries should shift to commercialize $S$. melanotheron and $G$. paganellus as they have stable populations, high protein contents, and lower commercialization strengths, instead of only using these species as aquarium displays, gamefish, and fish baits. In contrast, the values obtained in photometry for $M$. cephalus, O. cavitensis, and S. tawilis were positive. The study also revealed that these species protein contents were larger than that of $H$. quoyi and A. duodecimalis.

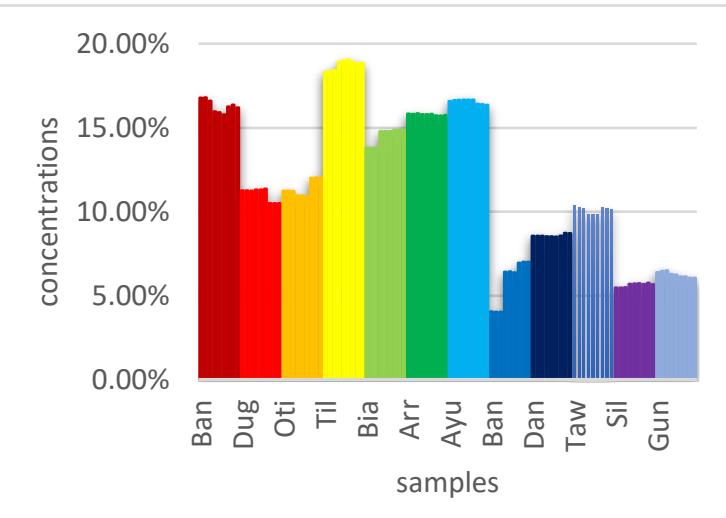

Figure 4. The protein concentration plot of the photometry at $280 \mathrm{~nm}$ using ovalbumin assay.

Ovalbumin had \% RSDs at 0 to $4 \%$, which are in the acceptable values for replication. This $\%$ RSDs were smaller than that of photometry but larger than of Bradford. The distribution is Gaussian (Table 5). ANOVA revealed an F statistic value $(254.0951)>Q$ critical value (4.1498) which strongly suggested that the methods were significantly different at a $P$ value of $1.1102 \times 10^{-16}<0.01$. Post-hoc Tukey HSD test supported these findings by comparing $Q$ statistic values with a $P$-value of $0.0010053<0.01$ for all the comparisons, and a $Q$ critical of 4.1498: ovalbumin vs photometry (a $Q$ statistic of 18.2578), ovalbumin vs Bradford $(Q$ statistic of 13.5046). Evaluating $T$ statistic values, Scheffe test revealed the methods were significantly different at a $P$-value of 
$1.1102 \times 10^{-16}<0.01$ and $Q$ critical of 4.1498: ovalbumin vs photometry (a $T$ statistic of 12.9102), ovalbumin vs Bradford (a T-statistic of 9.5492). The $P$-values were evaluated by the BHMC tests, which supported the arguments above with Bonferroni and Holm $P$-interference values of $0.0000<0.01$. The BH $T$-statistic values for the comparisons of ovalbumin to photometry was 12.9102, and to Bradford was 9.5492. The statistical premises above suggested the efficiency of ovalbumin than photometry, and its limitations to Bradford.

\section{Protein Quantification using Bradford} Assay. The equation for the protein quantitation at $595 \mathrm{~nm}$ using Bradford's assay was $\mathrm{y}=0.4445 \mathrm{x}+0.0586$ with a correlation coefficient of 0.994 which suggested a linear relationship between protein standard concentration and absorbance (Fig. 2). The \% RSDs for all the protein standards were less than $15 \%$ which suggested the precision in the preparation of the Bradford's standards. The protein concentration values using Bradford's assay were not consistent with the previous methods. Specifically, all values were within the 15 to $20 \%$ range (Fig. 5) which is in agreement with the publish protein concentrations (Torry Research Station, n.d.). The $\%$ RSDs were below 1\% which suggested

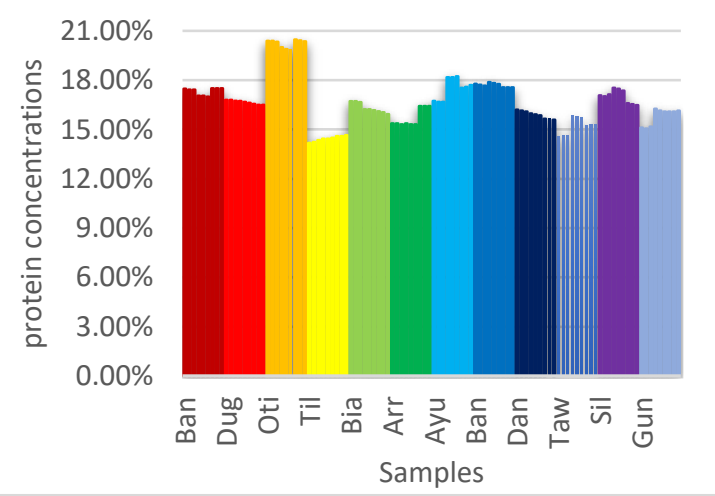

the high reproducibility of the method.

Figure 5. The protein concentration plot for the Bradford's assay.
The species at the upper $50 \%$ of the values were not consistent with the previous methods, except for $C$. chanos, P. leopardus, and L. plumbeus. $P$. leopardus had the highest protein concentration at $20.2341 \%$, which satisfies its market price (Heemstra \& Randall, 1993). P. leopardus has high commercialization strength due to its white meat. This was followed by $M$. cephalus at.17.6984\%, L. plumbeus at $17.3232 \%, C$. chanos at $17.3232 \%, H$. quoyi at $17.0201 \%$, and $A$. semipunctata at $16.6546 \%$. The protein contents of $M$. cephalus and $C$. chanos were in agreement with their relative market prices and commercialization strengths (Harrison, 1995; Bagarinao, 1994). Although these species were classified by the International Union for Conservation of Nature as not vulnerable for extinction, $M$. cephalus's and C. chanos's populations are being threatened by exploitations of aquatic resources, modifications of natural systems, and invasions of alien species (Camara, et al., 2017; Freyhof, et al., 2017). In contrary, $H$. quoyi, and $A$. semipunctata have lower commercialization strengths and typically used as displays in aquariums, gamefish, and fish baits (Collette \& Su, 1986; Myers, 1991). These species' populations are stable. $L$. plumbeus's population is decreasing because of sedimentation and pollution; thus, this species is not a good candidate for alternative commercialization (Santos, 2010). Species with stable populations and high protein contents but with lower commercialization, such as $H$. quoyi and $A$. semipunctata, should be commercialized more than the unstable expensive species such as P. leopardus, $M$. cephalus, and $C$. chanos. Aquacultures and fisheries should shift to commercializing $H$. quoyi and G. paganellus as they have stable populations, high protein contents, and lower commercialization strengths, instead of only using these species as aquarium displays, gamefish, and fish baits. L. plumbeus should be bred in close captivities to support their commercialization. O. niloticus had the lowest protein concentration despite having the high protein content from the two methods. Interferences from the ribonucleotides have 
affected the absorption readings. Furthermore, 0 . niloticus's protein content is not in agreement with its commercialization strength. It is recommended to lower the commercialization of $O$. niloticus's as its stable population is continuously threatened by overexploitation of aquatic resources, pollution, and alien species invasion. The superiority of the Bradford's assay among all the methods employed were derived from its absorption peak at $595 \mathrm{~nm}$ (Fig. 6), which has no interfering signal. The Bradford's reagent is very specific for lysine and arginine residues providing higher sensitivity, replicability, and specificity among the

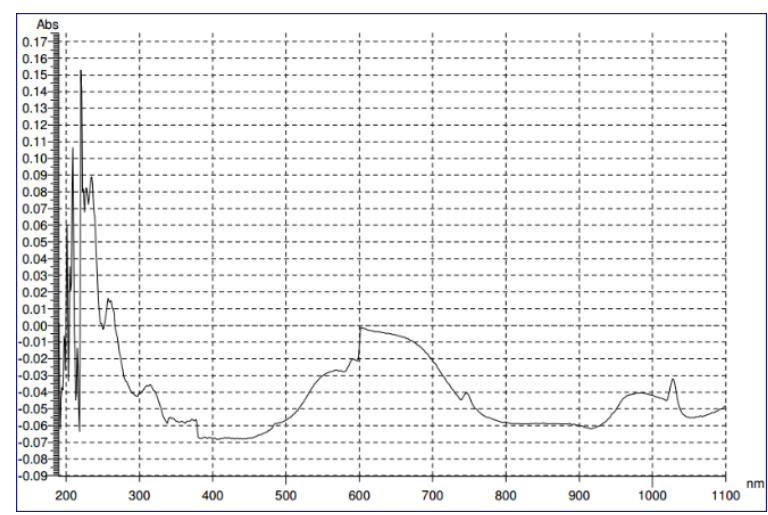

methods.

Figure 6. The absorption spectra of proteins reacted with Bradford's reagent from 190 to $1100 \mathrm{~nm}$ with an isolated maximum absorption at $595 \mathrm{~nm}$.

Ovalbumin had the most precise replication among the methods employed. The distribution is Gaussian (Table. 5). ANOVA revealed an $\mathrm{F}$ statistic value $(254.0951)>Q$ critical value (4.1498) which strongly suggested that the methods were significantly different at a $P$-value of $1.1102 \times 10^{-16}<$ 0.01 . Post-hoc Tukey HSD test supported these findings by comparing $Q$ statistic values with a $P$-value of $0.0010053<0.01$ for all the comparisons, and a $Q$ critical of 4.1498: Bradford vs photometry (a $Q$ statistic of $31.7624)$, Bradford vs ovalbumin $(Q$ statistic of 13.5046). Evaluating $T$ statistic values, Scheffe test revealed the methods were significantly different at a $P$-value of
$1.1102 \times 10^{-16}<0.01$ and $Q$ critical of 4.1498: Bradford vs photometry (a T-statistic of 22.4594), Bradford vs ovalbumin (a Tstatistic of 9.5492). The $P$-values were evaluated by the BHMC tests, which supported the arguments above with Bonferroni and Holm $P$-interference values of $0.0000<0.01$. The BH $T$-statistic values for the comparisons of Bradford to photometry was 9.5492, and to ovalbumin was 22.4594. The statistical premises above suggested the superiority of the Bradford's assay among the methods employed.

\section{CONCLUSIONS}

Bradford's Assay was the ideal method with an RSD of less than $1 \%$ for all the samples, with no negative concentrations, and with protein concentrations ranging from $15 \%$ to $20 \%$. P. leopardus had the highest amount proteins, followed by $M$. cephalus, $L$. plumbeus, $C$. chanos, $H$. quoyi, and $A$. semipunctata. Interestingly, the study revealed that $O$. niloticus, which is one of the species with a high market price had the lowest protein concentration. With these results, the lowly commercialized fishes such as M. cephalus, L. plumbeus, $H$. quoyi, and $A$. semipunctata which are used as gamefish, fish bait, and aquarium displays should be commercialized more than the unstable populations of $P$. leopardus and $C$. chanos. Overall, this study revealed comparative information on protein quantitation methods, and market price-nutritional values correspondence.

\section{REFERENCES}

Allen GR. Apogon virgulatus Allen \& Randall, a junior synonym of Apogon cavitensis. World Register of Marine Species. 1995; 22(1-2):10.

Bagarinao T. Systematics, distibution, genetics and life history of milkfish, Chanos chanos. Environ Biol Fish. 1994; 39(1):23-41. https://doi.org/10.1007/BF00004752 
Bio-Rad Laboratories. A guide to polyacrylamide gel electrophoresis and protein extraction. United States of America: Caliper Life Sciences Group.

Camara K, Carpenter KE, Djiman R, Nunoo F, Sagna A, Sidibe A, . . . Sparks JS. Mugil cephalus. The IUCN Red List of Threatened Species 2017:e.T135567A20682868, doi: 10.2305/IUCN/UK.2017-

3.RLTS.T135567A20682868.

Carpenter KE, Smith-Vaniz WF, de Bruyne G, de Morais L. Gobius paganellus. The IUCN Red List of Threatened Species 2015:e.T198662A21913408. http://dx.doi.org/10.2305/IUCN.UK.20154.RLTS.T198662A21913408.en.

Choat JH, Samoilys M. Plectropomus leopardus. The IUCN Red List of Threatened Species 2018:e.T4468A100462709. doi:10.2305/IUCN.UK.2018-

2.RLTS.T4468A100462709.en

Collette BB. Family Hemiramphidae gill. Halfbeaks California Academy of Sciences Annotated Checklists of Fishes. 1859; 22:135.

Collette BB, Su J. The halfbeaks (pisces, beloniformes, hemiraphidae) of the far east. Proc Acad Nat Sci Philadelphia. 1986; 138(1):250-302.

Freyhof J, Sparks JS, Kaymaram F, Feary D, Bishop J, Al-Husaini M, ... Al-Khalaf K. Chanos chanos. The IUCN Red List of Treathened Species 2017:e.T60324A3098466, doi: 10.2305/IUCN.UK/2017-

3.RLTS.T60324A3098466.

Froese R, Daniel, P. Ayungin. FishBase. http://www.fishbase.org/Summary/SpeciesS ummary.php?ID=4872\&AT=ayungin. 2010.

GE Healthcare Life Sciences. Protein sample preparation handbook. GE Healthcare Life Sciences. 2014. 28-9887-41.
Harrison IJ. Mugilidae Lisas. In: Fischer W, Krupp F, Schneider W, Sommer CC, Niem V. Guia FAO para Identification de Especies para lo Fines de la Pesca. FAO, Rome: Pacifico Centro-Oriental. 1995. p. 1293-1298.

Heemstra PC, Randall JE. FAO Species Catalogue. Vol. 16. Groupers of the world (family Serranidae, subfamily Epinephelinae). An annotated and illustrated catalogue of the grouper, rockcod, hind, coral grouper and lyretail species known to date. Rome:Fisheries and Aquaculture Fisheries Synopsis. 1993.125(16):382.

Helgi Library. Fish consumption per capita in the Philippines. Helgi Analytics. Czech Republic. 2018. Retrieved from https://www.helgilibrary.com/indicators/fis h-consumption-per-capita/philippines/

Herre AW. Check list of Philippine fishes. Records of the U. S. Fish and Wildlife Service. 1953; 20:1-977.

Ivantsoff W. Atherinidae. In: Fischer W, Bianchi $G$, editors. FAO species identification sheets for fishery purposes Western Indian Ocean fishing area 51. 1983.

Jasco Corporation. Protein quantitation using a uv-visible spectrophotometer. Mary's Court, Easton: Jasco Corporation.

Kruger NJ. The Bradford method of protein quantitation, 2nd Edition. Totowa, New Jersey: Humana Press. 2002.

Labconco. A guide to freeze drying in the laboratory. Labconco Corporation. 2010, 3$53-8 / 10$.

Maufe LA. Gobiidae. In Daget J, Gosse JP, Thys van den Audenaerde DF. Check-list of the freshwater fishes of Africa (CLOFFA). Brussels:MRAC, Tervuren, ORSTOM. 1986. p. 358-388.

Myers RF. Micronesian reef fishes. Second edition. In Myers R. F, Micronesian reef fishes. 
Second edition. Barrigada, Guam:Coral Graphics. 1991. p. 298.

Philippine Statistics Authority. Fisheries statistics of the Philippines. 2017.

Rao H, Li B, Yang Y, Ma Q, Wang C. Proteomic identification of organic additives in the mortars of ancient Chinese wooden buildings. Anal Methods. 2015; 7:143-149.

Santos BS, Fontanilla IKC, Quilang JP. Geometric morphometric analysis and gill raker count variation of population of the endemic Philippine silver perch, Leiopotherapon plumbeus (Perciformes: Terapontidae). Philipp Agric Sc. 2010 Dec; 93(4):406-419.

Snoeks J, Freyhof J, Geelhand D, Hughes A. Oreochromis niloticus. The IUCN Red List of Threatened 2018: e.T166975A49922878. http://dx.doi.org/10.2305/IUCN.UK.20181.RLTS.T166975A49922878.en. .

Trewavas E. Tilapiine fishes of the genera Sarotherodon, Oreochromis and Danakilia. London, U. K.:British Museum of Natural History. 1983.

Trewavas E, Teugels GG. Sarotherodon. In: Daget J, Gosse JP, Teugels GG, Thys van den Audenaerde DF. Check-lit of the freshwater fishes of Africa (CLOFFA) Volume 4. Brussels, Tervuren, and Paris: ISNB, MRAC, ORSTOM. 1991. p. 425-437.

Torry Research Station. Fish protein concentrate. Food and Agricultural Organization Corporate Document Repository. Available at www.fao.org/wairdocs/tan/x5917E/x5917e 01.htm.

Ubiali A, Cadei M, Grigolato PG. Spectrophotometric assessment of nuclear proteins: A preliminary study. Eur J Histochem. 2004. 3:329-334.
Whitehead PJ. FAO species catalogue vol 7. Clupeiod fishes of the world (suborder Clupeoidei). An annotated and illustrated catalogue of the herrings, sardines, pilchards, sprats, shads, anchoves, and wolf-herrings. Journal of FAO Fisheries Synopsis. 1985; 125(7/1): 1-303.

book 9, chap. A4, September 2006, accessed [2018, Nov 8], at http://pubs.water.usgs.gov/twri9A4/.

World Health Organization (WHO), Guidelines for Drinking-Water Quality, WHO Press, Geneva, Switzerland, 4th edition, 2011. 